
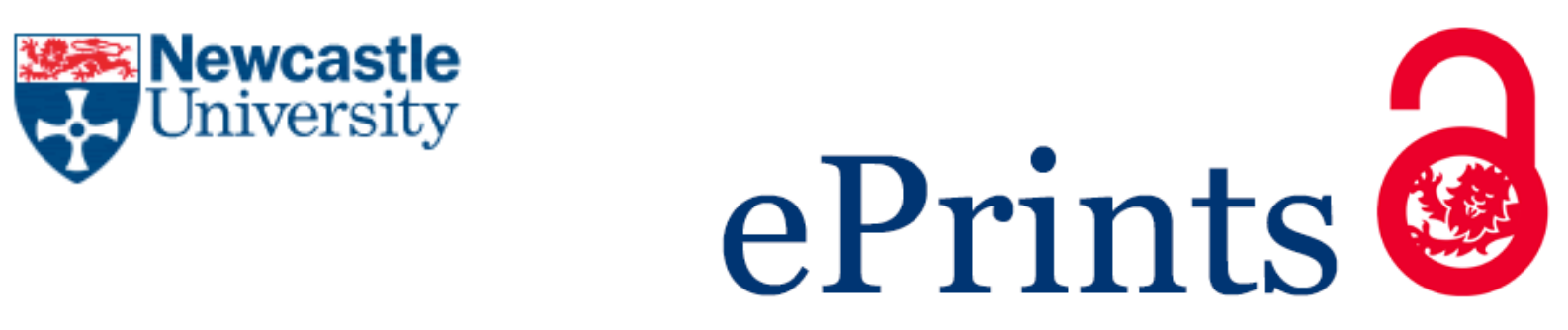

Shaw R.

Knowing Homes and Writing Worlds? Ethics of the 'Eco-', ethics of the 'Geo-' and how to light a planet.

Geografiska Annaler: Series B, Human Geography 2017, 99(2), 128-142.

\title{
Copyright:
}

This is an Accepted Manuscript of an article published by Taylor \& Francis in Geografiska Annaler: Series B, Human Geography on 11/04/2017, available online: https://doi.org/10.1080/04353684.2017.1311469.

Date deposited:

$24 / 03 / 2017$

Embargo release date:

11 April 2018

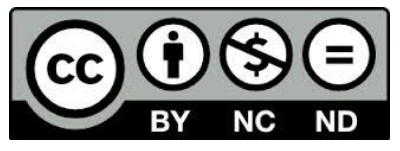

This work is licensed under a

Creative Commons Attribution-NonCommercial-NoDerivatives 4.0 International licence 


\section{Knowing Homes and Writing Worlds? Ethics of the 'Eco-', ethics of the 'Geo-' and how to light a planet}

This paper is an attempt to explore the relationship between the 'eco-' prefix of the term 'ecosophy' and the 'geo-' prefix of the term geography. While their linguistic distinctions are well established, this paper will delve into the conceptualization of 'earth' that the use of each prefix prioritizes. My aim is to show how the geo- prefix has pushed geographers towards conceiving of the earth as a surface across which differences are spread, whereas the eco- prefix pushes us towards a conceptualization of the earth as 'home', potentially a more holistic imagination. In order to explore the differences that these conceptualizations produce, I focus on the ethics that they push us towards, particularly in consideration of how humans relate to the earth. I trace a history from Hartshorne's description of the discipline of geography through to a series of examples of 'geo' oriented ethical writings, before turning towards the ecosophies written about (separately) by Arne Naess and Felix Guattari. In so doing I also explore the shift that Guattari makes to an ecosophy from the 'geophilosophies' that he wrote in his earlier work with Deleuze. In order to illustrate the application of these ideas to geography, I explore them in relation to various contemporary debates about artificial lighting in the context of climate change, light pollution, mobilities and use of energy. The argument overall here is that while the geo and the eco share multiple values, the addition and consideration of the earth as 'eco' might push geography towards a greater reflection as to how we relate to the earth and to others who might call it home.

Keywords: Ecosophy, Earth, Geographical Theory, Lighting, Environment, Ethics 


\section{Knowing Homes and Writing Worlds? Ethics of the 'Eco-', ethics of the 'Geo-' and how to light a planet}

"If geography is man's way of setting down his understanding of the earth, then the significant stages in advancing geographic thought should be marked by notable extensions of man's comprehension of the earth-body" (Whittlesey, 1945, p1)

Geography has spent much of its history considering itself to be man's - very often in both the sense of 'male' and 'humanity' - knowledge of earth. But what if we reverse this question? Deleuze and Guattari, title one of their 'plateaus' with the question "Who Does the Earth Think It Is" (Deleuze and Guattari, 1987, p44). They are just one of a large group of thinkers who have established a sense of the earth as a 'who' rather than an 'it', whether along a quasi-spiritual basis (as with Lovelock's Gaia) or as part of a range of materialist, indigenous and monist philosophies. While these schools of thought may differ on a range of other themes, they all come to an understanding of earth as some sort of 'person', broadly conceived. While geography, social science and social theory more broadly has extensively drawn from a range of perspectives to rethink 'human' (Braidotti, 2013), we have tended to take the Earth much more for granted. In realist ontologies the Earth is the field of geographical study: the object that we photograph, measure, observe and explore. Under constructivist ontologies, the Earth is the product of both our research and society. Both of these dominant approaches speak to the etymological meaning of geography as 'earth-writing': the former writes about the earth, the latter produces the earth through its writing.

In this paper, I want to explore the implications for the discipline if we put the agency and being of the earth more centrally in geography - if we take Whittlesey's 'earth-body' more literally. In approaching this question, I want to explore if an 'ecosophical geography' might offer a way of doing this. In particular, this paper is an attempt to develop an understanding of different perspectives on the earth that have been generated variously by the 'eco' or the 'geo'. Informing this is my research interest in the shift seen in Guattari's work from his 'geophilosophy' written with Deleuze (Deleuze and Guattari, 1987, Deleuze and Guattari, 1994) to his 'ecosophy' that he develops in his later writings (Guattari, 1995, Guattari, 2000, Shaw, 2015). While it is tempting to see this as a simple terminological difference, I see a deeper conceptual shift happening here. Specifically, the eco and geo seem to push us towards differing positions on what the Earth is and how we ought to relate to it. In this article we will establish some of the ways that this has resonated across contrasting theorists that have influenced geographical thought, before exploring what a merging of the geo and the eco might offer, that is, what an 'ecosophical geography' might bring to the discipline.

The paper begins by turning to Hartshorne's 1939 classic The Nature of Geography. The aim here is to illustrate how debates over the nature of the earth, and its role in geographical study, were once more current in the discipline. By focusing on these, I show how geography came to settle on a concept of the earth as 'surface', subject to human interaction. This idea has continued to resonate into the discipline today despite a move away from positivist and descriptive approaches which gave rise to it. I illustrate this through a series of contemporary discussions of ethics in geography: this is by necessity not a complete exploration of the discipline. Rather, the examples chosen show some of the variety of ways this conceptualisation of earth feeds into contemporary ways of imagining ethics in the discipline. Building on the ecosophical positions that this special issue explores, I explore the understanding of the earth as 'home' that is developed out of approaches which focus on the 'eco' rather than the 'geo'. Following this, I turn to the question of artificial lighting to pull out some of the ways in which an 'eco' oriented ethics might offer insights to key geographical questions. Through 
this, I offer a series of prompts for thinking that an ecosophical geography can bring to the discipline, and a description of the ways in which we can think earth and world together.

\section{A Geo-Graphical-Ethics, or How to Write Good Worlds}

\subsection{Origins of the 'Geo' as Surface}

Geography, as undergraduate students are taught, has its etymology in the Greek 'geo', meaning earth, and 'graphia', which is commonly translated as 'to write' but which might also translate as 'description' (Springer, 2014). Geographical thought, in particular driven by feminist (Rose, 1993), postcolonial (Jazeel and McFarlane, 2010), poststructural (Gregory, 1994) and participatory (Kinpaisby, 2008) discussions of methodology and the politics of knowledge production, has extensively reflected on the acts of description and writing. There has however, been much less reflection on the 'earth' element of 'earth-writing', with the world typically imagined either as a canvass/container onto which or within which action happens, or as a product of social or perhaps socio-natural interactions. Whittlesey, as quoted in the opening of this paper, conceives of the earth as the horizon for human activity. Under such a phrasing, the earth is rendered as of interest to geography only in so far as humans interact with it. Hartshorne explores this in more depth in his influential On the Nature of Geography, in which he traces the conceptualisation of geography - and in particular the question of what 'geo' geographers had studied - from the eighteenth to the earlytwentieth century (Hartshorne, 1939). He identifies the emergence of the distinction between study of the 'earth body' and study of the 'earth surface', which eventually became the disciplinary between the geological and the geographical. This follows Kant, who argues that geography should be the study of the world "so far as we can come in relation to it, the scene of our experiences" (Hartshorne, 1939a, p216). This distinction remained largely in placed through nineteenth century geography, in which the study of the earth outside of human experience was separated out from the discipline, with the major division of the discipline instead emerging as the 'human' and 'physical' components with which we are still familiar (Hartshorne, 1939a, p.219). Exceptions include several German geographers including Ritter, Humboldt and most notably for Hartshorne work of Gerland, who attempted to reimagine the earth as "an assemblage" (see Leighly, 1938), in an apparently coincidental use of terminology in relation to the contemporary concept. Instead, Hartshorne insists on a conception of Earth as human-homeland as important due to the Earth's unique position as the planet on which we live. The subsequent picture of the geo that Hartshorne describes for geography is of the earth's surface and its multisensorial appearance from a human perspective. Hence his summary that:

"Geography, in particular, studies the spatial sections of the earth's surface, of the world. Geography is therefore true to its name; it studies the world, seeking to describe, and to interpret, the differences among its different parts, as seen at any one time" (Hartshorne, 1939b, p636)

Hartshorne's work here reveals a discipline that has its name as a clear guide for its practice. While geography may have evolved in various ways since Hartshorne's writing, it has I think continued to take its name seriously as a guide to its practice. As such, the geo with which much of geography has operated has been a geo in which the earth is understood first, as subject to humanity and second via its surface appearance.

Hartshorne's distinction falls into a long history of "the surface/depth dichotomy" (Lata and Minca, 2016, p.439). Forsyth et. al. trace the surface as a concept within geography, revealing the deeper history on which Hartshorne is relying (Forsyth et al., 2013). Their work, part of a special collection 
exploring 'surfaces', reveals a return to the theorisation of a concept which had been somewhat lost from explicit discussions in the discipline. A feminist critique has engaged with the limitations of the concept of surface: for Rose, to describe something as a surface is to render it a spectacle to be viewed (Rose, 1995). Further feminist reflections on surfaces have emphasised their permeability, and the connections between surface and depth (Bosworth, 2016). Alternative visions of surface which look to move beyond the surface as spectacle are seen in Forsyth et. al.'s special issue, as well as Wylie's (2006) attempt to view surfaces as more complex, folded and topographical. Such conceptualisations are useful in revealing the limitations of 'surface' as a concept, but this is somewhat distinct from the legacy that the placing of surface implicitly at the heart of geographical thought has produced. In other words, while the critiquing and complicating of surfaces is of interest, this does not undo the unwritten legacy that equating the earth with a surface subject to humanity's action has created.

\subsection{The 'Geo' as surface in geographical ethics}

In the next part of this section, I want to take some well-established geographical writing on ethics and explore how these ideas have been shaped by the conceptualisation of the 'geo-earth' as established above. In particular, I argue that this understanding of 'geo-earth' has led to geographers focusing on particular understanding of relationality, based upon cross-earth dependency, relations with difference, and commitments to Other(s). Clearly these are important aims but they are, I argue, limited. In particular, these 'geo-earth' ethics have tended to emphasise relationality based on human connections across the earth. An influential example of this is Massey's ethics based upon the relationality of space.. She argues that there has been a "political abandonment of the security of a grounded identity in what we might call the old sense" (Massey, 2004, p5). In other words, in response to conceptualisations of identity as fragmented and contingent, Massey turns towards geographical relations as a source of ethics. Massey starts from the position that "any nation, region, city, as well as being internally multiple, is also a product of relations which spread out way beyond it" p6. She develops this further, reminding us of "the groundedness, the emplacement, even of so-called 'global' phenomena" p8. In other words, the starting points for Massey's geo-ethics is that all places are meaningful to some people, and that all places are interconnected. Amin summarises the spatiality of such an approach:

The tracings of varying length and duration of material, virtual and immanent relationships that work through a place called London or a Bedouin camp, that mesh with a genealogy of past spatial relationships, to nudge London and the Bedouin camp in new directions of force and expression. So, if we are to see cities and regions as spatial formations, they must be summoned up as temporary placements of ever moving material and immanent geographies, as 'hauntings' of things that have moved on but left their mark" (Amin, 2004, p34)

Amin and Massey's phrasing reveals a version of the geo understood through in the spread of human activity across surface. In other words, we need to value our actions both on a local basis and a global basis because of the effects that they will have on others simultaneously across these scales. While such a position does not inherently deny the value of the earth outside of human life, we can see in its formulation the legacy of the concept of 'geo-earth' as described by Hartshorne. Although the spatiality of human interactions behind this vision of geographical ethics can be nuanced (Darling, 2009), the earth that it relates to is nonetheless by-and-large a shallow one in a geological sense, produced by human relations between places on the surface. Such an approach might be understood as a geographical equivalent of 'correlationism', that is, the philosophical 
principle that "we only ever have access to the correlation between thinking and being, and never to either term considered apart from the other" (Meillassoux, 2008, p5). ${ }^{1}$ Such geographical ethics based upon human relations across the Earth's surface may be understood as a form of Geocorrelationism', in which we can only have a relationship with the Earth through our (literally) superficial interactions with each other across it.

This position exemplified by Massey is just one approach to ethics within geography, but exemplifies the ways in which the discipline has been influenced by a geocorrelationist understanding of the world-self relation. . I want to move on to construct an alternative framework for how an 'eco' oriented ethics might offer fresh perspectives for the discipline. Before doing this, though, it is worth noting that there are other approaches that have made similar interventions. Harrison posits an understanding of the earth as a gap, a space or an impasse between people (and indeed between all actors). Here, the concept of dwelling acts as his way into the geo, implying as it does a relationship between the self and the world - between the dweller and the location in which dwelling happens. In particular, Harrison draws from Levin as' version of 'dwelling', in which the act of inhabiting and dwelling generates multiple separate worlds, each independent of Others, but equally dependent upon interacting with Others. As Harrison argues, this relies upon,
"the radical separation and isolation of the self. However, it is necessary to understand that for Levinas this separation or isolation is not the self- realising or acceding itself but rather is a form of rapport: a profound solitude of intimacy, the very event of a primary and radical pluralism." (Harrison, 2007b, p643)

Here, the geo of Harrison's geography is still a world produced and maintained by humans, but one which is also inherently dependent upon other inaccessible worlds. We are always 'falling short' (Harrison, 2007a) of other worlds, but this is a constitutive part of being-in-the-world. Harrison's intervention does not reject outright a geography which sees the world as constructed on or around humanity (Harrison, 2011). Rather, what differs the geo in his work from that of the relational perspectives previously described is the emphasis on world as space in-between selves, in which there is no total system of relations. While still based on the distant effects and the geographical ripples of local actions, Harrison moves us towards a more uncertain and more tentative ethics which acknowledges the impossibility of doing no harm in our relating to the world. A second way in which geographers have begun to move beyond a geocorrelationist ethics is through 'more-thanhuman' geographies. This description covers a variety of contemporary geographical positions, including areas influenced by actor-network theory, non-representational theories and practice theories. These seek to explore "the vital connections between the geo (earth) and the bio (life)" (Whatmore, 2006, p600). This work brings to geography a number of actors which fall outside of the human-earth relationship, arguing that multiple materials contribute "to the intimate fabric of corporeality that includes and redistributes the 'in here' of human being" (Whatmore, 2006, ,602). More than human geographies have been paralleled in other disciplines, with an increasing proliferation of work which identifies and recognises the liveliness of objects, infrastructures and 'things' (Bennett, 2004, Demant, 2009, Miller, 2001).The understanding of the geo-, and the ethical implications of this work, is only slowly being developed, but we can identify two emergent trends within it. The first are approaches which, while diversifying the actors involved, do not significantly move us beyond the geocorrelationist world and ethics. We might identify much of the work in

\footnotetext{
${ }^{1}$ It should be noted that Meillassoux gives this position this label as a form of criticism, though that is not the intention here
} 
practice theories here, and while this is a productive area of thought it is of less interest here, retaining as it does a focus on the earth as surface. A second tendency has been work which turns more radically to the earth in its planetary, environmental and geological characteristics. Influences here are varied, incorporating Deleuze and Guattari's geophilosophy, postcolonial theories which have emphasised the heterogeneity of the production of being, actor-network theories that have rejected the concept of 'things' existing outside their relations, and most recently work on the concept of Anthropocene.

The Anthropocene and associated ideas push geographers who have become interested in the complex relationship between humans and non-humans towards radically rethinking the position of the earth in geography. Simply put, the Anthropocene as a concept inherently binds humans and earth together. This has encouraged geographers working in this area to consider a deeper materiality of the earth, stretching down into the earth's geology and up into its atmosphere, returning the discipline to "its historic origins as a subject devoted to studying the complex relations between people and their environments" (Castree, 2014, p451). Bastian, for example, emphasises the need to rethink the relationship between time and society in understanding environmental crisis(Bastian, 2012). She explores the way that various social scientists and philosophers have argued that our understandings of temporality have contributed to a lack of action in relation to the claims of climate change and the Anthropocene. She argues that, "far from being able to coordinate our actions with the significant changes our world is currently undergoing, we are increasingly out of synch" (p24). Her diagnosis of a failure to recognise the performativity of time management and temporal claims, with a need for new ways of configuring time to be more-in tune with earth processes. Similarly, Clarke identifies Anthropocene as bringing challenges for understanding of temporality, extending as it does contemporary action into both the past and the future (Clark, 2016).From Bastian and others who have explored Anthropocene, a clear ethics of the earth can be seen here, in which we need to "'coordinate" ourselves with and through other relationalities within our world" (p45). By deepening geologically the scope of geographical work, and extending this view in time, this stretches us beyond the 'surface' that much 'geo-earth' work has implied.

To repeat, in exploring the various geo- ethics set out above - which are inevitably only a selected portion of geographical work - we see that Massey's relational ethics is typical of many positions in geography which take as their starting point an implicit understanding of 'geography' as the writing of the ways of living on the earth's surface. This guides us towards a relational 'geocorrelationist' ethics, centred on the ripples of our actions across these surface relations, whereby choices and decisions are to be made according to their outcomes in a largely human-centred world. The subsequent work considered complicates this, offering some of the ways that geographers have tried to move beyond 'geocorrelationism' From Harrison, we see an approach which denies the possibility of this relational ethics; or rather, work which shows that this ethics must always incorporate a level of failure in relations. Here, we are invited to focus much more on co-created selves and worlds always in separation from one another. A larger area of research focuses on bringing a range of different actors up to the levels of humanity in the creation of worlds. In its 'strongest' version, this work invites us to ask what the world thinks of itself; it populates the world with a vast array of actors of equal footing to humans. Such research has opened up geography for a rethinking of our ethical relation to the world, but so far this has not been fully developed. In the next section, I want to build on this school of thought by turning to the geophilosophy of Deleuze and Guattari and its development by Guattari into an ecosophy. I will explore the ways in which this shift from geo to eco reveals a shift in the vision of 'earth', and humanity's relationship to it, which is placed at the heart of any ethical claims. 


\section{An Eco-Sophical-Ethics, or, How to Know Your Home}

\subsection{The origins of the 'eco'}

Beginning again with etymology, we find in the 'eco' of ecosophy a much more recent coinage. It is recent enough to be identifiable as the work of a single person, the biologist Ernst Haeckel. Haeckel coined the word 'ecology' to describe "the science of the economy, of the habits, of the external relations of organisms to each other, etc.", that is, the "conditions of existence" of life (Haeckel, 1866 in Stauffer, 1957, p140). Here, the word Ecology (German 'Ökologie') was created from the Greek oikos, meaning house, dwelling place or habitation. Haeckel was strongly influenced by the concept of an 'economy of nature' that can be found in Darwin and Linnaeus (Stauffer, 1957), and as such the prefix is connected to the 'economy', the origin of which can be found in the idea of household economics. Ecology was thus the study of the conditions of home, but also - as Haeckel sets out - the effects that these conditions of home would have on the organisms that inhabit it. The use of the prefix 'eco' as independent from this term is even more recent, first attested to in the 1960s. The term ecosophy, as coined independently of each other by Naess and Guattari, therefore, was following a linguistic trend less than 20 years old at the time. The suffix '-sophy' will be familiar to many as meaning the 'knowledge', as in 'philo-sophy' or 'the love of knowledge', from which the term ecosophy emerged. It is thus that we reach the literal etymology of ecosophy as 'the knowledge of home'. Why might this interest us, then, in a move towards an ecosophical geography? One question is what happens when we shift from the geo to the eco, or then even what happens when we compound them into an ecogeo? A point to draw from the etymologies of ecosophy and geography is that geography starts with the earth as manipulated physical matter, as produced through writing or subject to writing. In other words, the 'geo' of geography is territory, earth written about and subject to human vision. Ecosophy, however, starts with 'home', starts with the inhabited earth and seeks to develop a knowledge of it. The direction of travel here is from the conditions of life and living, towards the organisms that live in and make home. In other words, a major distinction in the understanding of the human-earth relationship is implied by the etymology of these words.

\subsection{From 'Geo' to 'Eco' with Felix Guattari}

In moving towards an understanding of the eco, from the geo, the place l'd like to start is with the work of Guattari, particularly because his writing shows a move from a geophilosophy that he writes with Deleuze (Bonta and Protevi, 2004, Deleuze and Guattari, 1994) to an ecosophy in his later work. What move does this consist of and how does Guattari make it? To understand this we need to begin with geophilosophy. For Deleuze and Guattari, "thinking takes place in the relationship of territory and earth" (Deleuze and Guattari, 1994, p85). In other words, philosophy takes place in and produces which territories, which are systems of thought or ways of organizing the world, both materially and immaterially. These territories are constantly being remade in relation to both thought and earth, via a series of 'deterritorializations' and 'reterritorializations', with the former always containing something of the latter (p101). In other words, they call for an understanding of philosophy centres on 'immanence', the emergence of thought out of (spatialized and materialized) relations. The geo of Deleuze and Guattari is thus the very condition for thought itself: "the earth is not one element among others, but rather brings all the elements within a single embrace" (p85). It is, as established in A Thousand Plateaus, a "body without organs", constantly being remade through the production of 'strata', layers which give form to matter, imprison intensities and which lock "singularities into systems of resonance and redundancy... producing on upon the body of the earth molecules large and small and organizing them into molar aggregates" (Deleuze and Guattari, 1987, p45). In other words, it is the earth which literally 'grounds' processes and materials for Deleuze and 
Guattari, as an all-encompassing field full of potential, a field which can be thought or organized in any way, but which is also the condition for all forms of thought and organisation. As noted before, however, this earth which acts is a territory, or at least a series of territorializations. In other words, this is a stratified and encoded earth which is both restricted and restricts. Thus when earth is described as a condition of possibility, it is not as a milieu or a container. Rather, it is constantly being remade as an "intense point at the deepest level of the territory" (p373). From Deleuze and Guattari's collaborative work, we thus have earth as conditions of living, taking the form of current territorialisations but always consisting of multiple strata deposited by previous territorialisations.

In his subsequent work, Guattari develops an ecosophical ethics as he moves from a geophilosophy towards an ecosophy. This is based upon a conviction that contemporary ecological crises "can be traced to a more general crisis of the social, political and existential" (Guattari, 1995, p119); the result is a need to:

"reinvent social practices that would give back to humanity a sense of responsibility, not only for its own survival, but equally forth future of all life on the planet, for animals and vegetable species, likewise for incorporeal species such as music, the arts, cinema, the relation with time, love and compassion for others" ( $p 120)$

The earth of Guattari's ecosophy is one which is completely embedded with and produced alongside the self and society - it is the heart of the 'environmental ecology' that sits alongside the 'social ecology' and 'mental ecology' (Guattari, 2000). It is one which thus has a level of independence from - albeit still strongly relating to - selves and society. This sees a shift from the geophilosophy of his writing with Deleuze, in which the earth appears as agentic but already stratified: literally drilled into by 'Professor Challenger' (Deleuze and Guattari, 1987), the earth of geophilosophy is capable of deterritorializations when sufficiently damaged but is rarely seen as the agent of change in and of itself. It is, fundamentally, a geological and territorial earth consisting of strata rather than the earth in which strata, water, plants and animals are entwined into an 'environmental ecology', which seems to be more multiple and active than the earth of geophilosophy. Whilst in $A$ Thousand Plateaus, Deleuze and Guattari ask what the earth thinks of itself, in his ecosophy Guattari is seeking to produce "a new planetary consciousness" (Guattari, 1996, p267) which would embed the earth and environment into subjectivity.

So the earth of ecosophy is for Guattari an earth embedded within all aspects of being, with power outside its stratified territorialisations, but it is also an earth in crisis, spawned by the general crisis of subjectivity in which "the relationship between subjectivity and exteriority - be it social, animal, vegetable or Cosmic" is compromised (Guattari, 2000, p19). Social crises, ecological crises and political crises which characterize the post-Cold War era are all manifestations for Guattari of this underlying problematic. Here, Guattari inherits insights from Bateson, who argues that the contemporary model of the self is 'pathological' (Bateson, 1973, Shaw, 2015). Bateson draws from the principle that the unit of survival proper to evolution is not the organism or the species, but "the interaction between organism and environment" (Bateson, 1973, p489). Through this theorisation, he makes no distinction made between self and world, between ecology and mind. Like Bateson, Guattari turns towards an ecosophy because of what he sees as a necessary realignment of contemporary ways of living. Consequently, the move from a geophilosophy towards an ecosophy is undertaken not because of a perceived flaw in geophilosophy per se; rather, a mixture of global events and a pathological subjectivity result in a need to produce new ways of thinking that are in harmony with the earth. In other words, it is not just necessary to call for the rejection of bourgeoisie and bureaucracy, but to also "determine with precision what one intends to put in their 
place" (Guattari, 1995, p122). Guattari's ecosophy is thus focused on the production of new forms of subjectivity as part of forms of living in harmony with earth and production: Guattari "believed that ecology, generalized as ecosophy, could help summon forth new productive traits of subjectivity" (Herzogenrath, 2009, p12, Genosko, 2009). Hence the need for an ecosophy, a wisdom about home, with an embedded ethics. Indeed, Guattari puts the ethical dimension of this at the core of his thinking through his description of ecosophy as 'an ethico-aesthetic paradigm'. Knowledge, and care for, the home is required in order to have knowledge and care for both our selves and our environment(s).

\subsection{Ecosophies beyond Guattari}

As papers in this volume indicate, however, there are further possible sources for an ecosophical geographical ethics. Naess' use of the term ecosophy predates Guattari, though there is no evidence of Guattari citing Naess or having read his work (Genosko, 2000). While Guattari's ecosophy is centred on the necessity of thinking self and world together, Naess' ecosophy has at its core a more inherent valuing of life, environment and world for its own sake. Like Guattari, Naess begins with the necessity to act due to crisis: "the crisis of life conditions on Earth could help us choose a new path with new criteria for progress, efficiency and rational action" (Naess, 1989, p26). He sees environmental crises as the opportunity for a realignment of humanity's ways of living in and with the earth, with eight core formulations, of which the first is that "the flourishing of human and nonhuman life on Earth has intrinsic value" (p29). So while both Guattari and Naess are driven by emergent crises, Guattari's ecosophy is developed out of a need to fix multiple 'anhtropoproblems' that he sees as being caused by a pathological subjectivity, whereas Naess' ecosophy is a response to the failure to value life on earth. Here, Naess is clearer as to why he uses the prefix 'eco-', which for him stresses that "we do not limit our concern for the life forms in a biologically narrow sense". The eco for Naess also applies to "watersheds, landscapes, cultures, ecosystems, 'the living earth"' (p29). The subject of Naess' interest is thus "the living conditions of organisms in interaction with each other and with the surroundings, organic as well as inorganic" (p36), which he summarises, aware of the term's etymology, as the "earth household" (p38). Viewing the earth as household in which all beings are of equal importance should, for Naess, result in an approach - a 'sophy', a wisdom towards the household which is embedded in care and support. Naess has been accused of naivety with regards to his understanding of human motivation and desire (Maskit, 2009), with his argument being that a proper understanding of the world and a proper system of thought will be sufficient to change practice (Naess, 1989). While Guattari's ecosophy has more centrally embedded within it a need for a radical change to subjectivity alongside a development of ways of relating to the world, deep ecology approaches that have emerged from Naess do not deny the difficulty of such change and the "realization and expansion of the Self" that is necessary (Rothenberg, 1995).

So the earth of a deep ecology approach to ecosophy is one which both determines and is determined by an extended self, as part of a "personal-planetary paradigm" (Drengson, 1995). While there are some differences between Naess and Guattari, their approaches probably share more than they differ on. The final form of ecosophical earth that I want to consider is one which takes a more radical departure away from the 'eco' as home. Though he does not use the term 'ecosophy' to describe his work, Morton's "ecological thinking" (Morton, 2010a) follows a similar path in putting the eco at the heart of his work. For Morton, this ecological thought is a "humiliating descent towards what is rather abstractly called the Earth" (Morton, 2010b, p195). Here, his claim is that ecological thought is one of the many ways that the centrality of the human has been eroded in philosophy, as humanity is gradually rendered as less and less special, becoming increasingly seen as 
a part of and intertwined with the world. Like Harrison's rendering of the impossibility of the relational earth as discussed above (Harrison, 2011) , Morton draws inspiration from Derrida's deconstruction as an attempt to explore the "structurality of structure" (Derrida, 1993) through the continuous play of 'difference', that is, "the process of difference and deferment" (Morton, 2010b, p197). Under this formulation, theories of interdependence demand that we understand the eco as a system of life forms of which there is no limit: once life 'begins' - everything else becomes linked with it" (p202). These life forms cannot, without logical inconsistency, be fully distinguished from either each other, or the 'environment', a term which, alongside 'nature', Morton rejects as limited. By exploring the persistence of elements of DNA across different species, the creation of 'environmental' changes such as the prevalence of oxygen in the atmosphere or the transformation of bones into fossil fuels, Morton makes a case for the claim that "there is no nature, never was, never will be" (p209). Like Guattari, he sees the world as shaped by the effects of science and capital and that "it is now the task of philosophy and politics to catch up" (p209). The eco of Morton's ecosophy is thus not a house or container, but rather a reduction of the world to recognise the interdependency of different practices and ways of behaving on each other - it is "intimacy, not holism" (p214). Morton describes this as a 'dark ecology' in which "we are hopelessly entangled in the mesh" (p222). In other words, Morton's Earth is more than the most we can know, it is the most that we can imagine being connected to.

These three ecosophies all offer ways of knowing home. In developing a framework for an ecosophical geography, I want to draw mainly from Guattari, but the approaches of Naess and Morton are also useful. An ecosophical geography conceives of the earth as coproduced with society and subjectivity, as a grounding of these with which we need to better connect to avoid complete destruction (Shaw, 2015). The eco has a value in and of itself, as established in Naess, but also a pragmatic value as contributory to our being as humans. To create knowledge of this home which produces us can both offer ways of imagining and establishing new forms of being, and place the well-being of the home more centrally in our research and thinking. Ecosophical ethics emphasises the interdependency of beings, which are always connected but always separated. The earth shifts from a territorialized agent subject to humanity and previous strata, to agent which has independence and being away from society and self. Ecosophical responses to problems will therefore emphasise intimacy, connection and the coproduction of selves and earths, at the same time as seeing potential conflict between these - Bateson's pathologies - where relations are imbalanced. Obtaining knowledge of the home thus requires obtaining knowledge about the self.

\section{How to Light a Planet: Between the Eco and the Geo}

\subsection{The Contemporary Challenges of Artificial Lighting}

Lighting the Earth is both a global question, and a modern one. Modern artificial lighting has its origins in the oil, gas and finally electrical lighting developed through the nineteenth century, which by the early twentieth century had already spread to cities on all continents (Lee, 2015). In the contemporary era, images of the world lit at night are regularly used to illustrate globalisation and concepts such as 'spaceship earth' or 'planetary urbanism' (see for example the use by Brenner, 2013, p.87), while public lighting also has significant impacts on everyday life on the smaller community or household scales (Bille, 2015, Steinbach et al., 2015). Amidst a period of technological change as I outline below, and in the context of emerging need to respond to climate change, there is a need to explore ethical approaches which would guide our understanding of the implementation of new technologies. In this section, I want to suggest a few prompts that the move from geo to eco, or perhaps more properly the merger of geo with eco, might raise for us when attempting to 
understand these implementations. . The aim here is not to provide definitive answers, but to illustrate how such shifts in our conceptualisation of earth might aid thinking.

The provision of public street-lighting has become an increasingly controversial and complex issue over the last decade. Authorities are having to balance out a series of competing environmental, economic, social and technological demands, desires, capacities and limitations in both developed and developing nations. Introduced in Europe in the eighteenth century and spreading globally through the nineteenth and twentieth centuries (Schivelbusch, 1988), the provision of public streetlighting was largely understood as a fairly uncontroversial public good - a measure of standard good government in the developed world, and a key marker of development elsewhere (Jakle, 2001). Local authorities were predominantly interested in how to produce more and brighter lighting for cities, in more locations. However, prompts from multiple sources have created a new complexity with regards to public lighting. These changes have been driven in part by recent technological innovations in lighting technology (Shaw, 2014, Kostic and Djokic, 2009). In particular, outdoor LED lights require less energy to achieve the same levels of illumination as previous lighting technologies (specifically, sodium-based lighting), and can be quickly switched on or off, as well as having their illumination levels altered. This has opened up the possibility for installing lower-energy lights, dimming of light levels, and part or all-night removal of lights; or more complex interventions of 'smart lighting', whereby illumination levels can be changed in response to: chronological and astronomical scheduling; social rhythms; animal behaviour; major events or security alerts; and realtime monitoring of traffic or other activity (Castro et al., 2013). Furthermore, due to their lower energy demands, LED lighting is also able to draw from solar-charged batteries, creating cheap and efficient street-lighting in previously unlit or off-grid locations (Costa et al., 2009).

These technological changes which allow for more efficient street lighting have emerged alongside a series of demands to reduce street-lighting. Increasingly, responsibility to adapt to and mitigate against climate change has been devolved to urban or regional governments, (Bulkeley, 2010) and street-lighting can represent a large percentage of these government's energy use (Shaw, 2014). In a developed world context, many local governments are now subject to long-term austerity economics (Peck, 2012), meaning that the high cost of street-lighting has become increasingly contentious. As such, the lower cost of LED and smart lighting has become attractive, with the possibility of 'dimming' or switching-off lights for part of the night being an incentive to change stock. There have also been pushes towards removing light entirely. Again, both cost and carbon use are important here, but the growth of the International Campaign for Dark Skies, campaigning for the protection of night skies in rural and suburban areas from light-pollution (Edensor, 2015), has encouraged the removal of some lighting. Changes in the developed world have centred on dimming lights or removing lights completely for either part or all the night, while in the developing world the installation of lighting has continued, although with a series of inequalities along gendered and racial lines (Kumar, 2015) as found in other infrastructural developments (Graham and McFarlane, 2014). Here, LEDs have been installed in many urban environments, while in rural areas more traditional lighting technologies continue to dominate, though as noted previously the connection between LED lighting and solar power has pushed its use in many places. Despite inequalities in access, the beneficial features of lighting that encouraged the belief in the need for well-lit urban, suburban and infrastructural areas remain. Jacobs argues that an active nocturnal population is a key feature of a lively urban neighbourhood (Jacobs, 1961). More broadly, lighting is frequently perceived as beneficial to economies, encouraging greater productivity, as well as facilitating education, urban mobility, and more egalitarian access to public space (Gaston et al., 2014). Perhaps unsurprisingly, this 'panacea' characteristic of urban lighting has not necessarily held where research has sought to establish definitive correlations between lighting and its perceived 
benefits. For example, research has failed to find a direct correlation between lighting levels and crime (Steinbach et al., 2015, Painter, 1996), though it has been established that the provision of targeted lighting schemes at crime-prone areas or other forms of investment that increase sociability at night can be effective (Painter and Farrington, 2001, Farrington and Welsh, 2002, Pain et al., 2006). Even though its benefits may be overstated, some sort of provision of artificial lighting clearly seems to have a range of potential benefits for urban life.

\subsection{Using the Geo and Eco to Understand Lighting Challenges}

So might the consideration of the eco and the geo together help us understand these different interventions in fresh ways? I want to approach this by a consideration of three key components of lighting the earth. The first is 'smart lighting' technology, and in particular the attempts to plan and control lighting through both pre-programming of lights and responsive systems. This deferral of responsibility away from people seems to run counter to the 'knowledge' element of an ecosophical approach, in which knowledge of how the home is operating is deferred to systematic control. While materialist geo-ethics may embrace socio-technical solutions, albeit with a critical lens, as solving and responding to 'surface' problems (Lawhon and Murphy, 2012), an engagement with the ecosophical would potentially push us towards more deeply interrogating the status of our knowledge of home which would permit the creation of algorithms that exercise some form of social control. In particular, such approaches would emphasise a more contingent and hesitant responses, rested in a geography of 'not-knowing' (Kitchin, 2014). Here, and drawing on the research already within geography which has taken such an approach (Pain et. al., 2006), we might see a demand for a series of local and contingent projects which are dependent upon local conditions, in both developed and developing contexts. Turning to Bateson, we note his emphasis on the dangers of 'hubris', and the error of the belief that technological corrections may fix other socio-environmental problems (Bateson, 1973, p.498-500). This is not to paint geo/surface ethics as somehow in thrall to technological solutions, but to emphasise the importance of the move towards a conceptual position that insists on the unknowability of the spiralling, detteritorializations that take place across a home and to which we open ourselves if we presume to produce systematic knowledge that will operate across multiple assemblages as if they were machinic, computerized systems. Perhaps the eco-geo's fist move, then, is to be more speculative in out understandings and localized in our ability to make claims.

Second, we might consider the broader need or desire for cities to have constant lighting. Relational approaches based upon a 'geo-graphical' ethics lean towards " an orientation to living with difference and everyday connectivity" (Darling, 2009, p.1947). Popke characterises this as the challenge of mixing a responsibility to place and specificity, with a responsibility to mobility, movement and encountering of difference (Popke, 2007). It seems likely that night-time artificial lighting would be valued under such a perspective: as highlighted previously, it opens up public space to greater levels of use (Jacobs, 1961), facilitates education and mobility for often marginalized groups (Green et. al., 2015), and acts more broadly as evidence of a space which is connected into wider global networks. As such, a relational ethics drawing from cosmopolitan and connectivity would highlight the value in all night lighting, and other work that keeps cities active through the night. By contrast approaches with an eco-focus might tolerate changes to human practice which offer a more harmonious relation to the earth, even if these were to threaten or damage global forms of mobility and movement. Naess, for example, argues that "no matter which one of the great philosophies one considers to be valid, our current role would be evaluated negatively" (Naess, 1989, p.87). Subsequent work in the 'deep ecology' tradition of ecosophy has emphasised technological transitions that move away from current levels of energy use (Aiken, 
2012), and in such frameworks extensive night-time artificial lighting would be seen as negative. While the positions of Naess and deep ecologists may be more extreme than many who use an ecobased ethics, it does reflect that the major gap between an orientation around the 'geo-' and an orientation around the 'eco-' may come at such moments where a decision is required between, on the one hand, technological or social developments that would facilitate interaction, mobility and cosmopolitanism, and on the other hand, any damaging effects of these that would impact on the security of the earth-as-home. While this gap may not be huge - a geo-graphical ethics of relationality would not call for extensive overlighting, and an eco-sophical ethics of knowing home would not call for the destruction of any technological capacity to create artificial light - there is nonetheless in this moment of decision making a tension around the hyphen of the 'eco-geo'.

The third intervention that I want to consider in the evolving world of artificial lighting is the spread of 'dark sky preserves'. The first dark sky preserve was created in 1999, and these have since spread under the regulation of the International Dark Sky Association, which authorises various differently scaled dark sky preserves: communities, parks, reserves or sanctuaries. These areas are spaces within which artificial lighting is controlled, in order to facilitate the observation of the night sky. Dark Sky areas have spread globally (Edensor, 2013), though they are found more frequently in areas of generally higher levels of artificial illumination, partially due to the greater need for protection but also because the creation of such areas has been driven primarily by the astronomical community, rather than by ecological concerns about light pollution (Bogard, 2011). From an ecosophical perspective, the value of such reserves would come from the ways in which they protect other creatures from light pollution. Of note, here, is that dark sky reserves have a depth within them, considering as the they do both the earth's surface, and the atmosphere as a layer surrounding this but connecting to it (McCormack, 2009). Furthermore, from an eco-based ethics, the capacity created by dark sky preserves to help people 'know home' by seeing and connecting with the nightsky would be valued (Daniel, 2011). By contrast, a geo- ethics of relationality might emphasise some of the critiques of these preserves: namely, that they have primarily been created to serve the needs of wealthy astronomical hobbyists and tourists from the Global North, in contrast to protecting skies that are being quickly lit in the Global South. As an intervention, then, they may be reinscribing forms of difference and social division amongst groups, offering protected dark sky access to a small and relatively wealthy interest group within the Global North. Within the scheme, however, is a potential 'geo-eco' goal of connecting people to both the skies as part of their home, and their local communities and landscapes. In other words, what the dark skies preserves might tell us is that the 'eco' may be best conceived of as additional to the surface ethics: the aim should be to incorporate a knowledge of home within the writing of our worlds.

\section{Conclusion}

A variety of empirical and conceptual prompts have started pushing geographers towards a deeper exploration of what was once one the key disciplinary debates, namely, the nature of the relationship between humans and the earth. These prompts have included the emergence of climate change as a key crisis of the twenty-first century; an engagement with poststructuralist and particularly Deleuzian geophilosophy; reimaginings of the self from a range of conceptual positions; and debates surrounding the concept of the Anthropocene. All of these have within them, both implicit and explicit theorisations of the human-earth relationship, and how it may or may not be evolving. Returning to Hartshorne (1939b), we can see that much geographical work has operated within the consensus that he describes of an earth defined by surface difference. Such an approach has understood the geo of geography to be the earth's surface and the differences that humanity has written onto this. While a pluralization of actors considered to be involved in this earth-human 
relationship has occurred over more recent decades, the work which has taken the 'strong' version of this materialist geography - that is, work which has started to radically redefine what participates in the earth-human relationship - is still limited in number. This paper has sought to contribute to the rethinking of earth through a focus on the 'eco', which helps achieve this reorientation by emphasising more centrally a deeper, interconnected sense of the earth as 'home', in which all features are intimately interdependent.

A major effect of this reorientation is to reposition the ethics of how we relate to the earth and to others who might call it home. If we conceive of earth as geo, as surface, then we inclined towards a surface-based ethics. These have emphasized connectivity and effects over distance, and have tended, as Bastian argues, to have a relatively short temporal imagination. An ecosophical geography of course does not throw this away: it is not about an 'either/or' choice between the 'eco' and the 'geo'. The earth-as-home is not a radical break from all thinking or philosophy beforehand, and as the section above should indicate, the exploration of these two approaches in relation to artificial lighting does not reveal a chasm between them. However, I hope to have shown that there are boundaries and markers at which an orientation around the geo-surface and an orientation around the eco-home may be distinct. In particular, ethics of the home will push us towards a greater consideration of the circular, ecological relations that would place a higher value on relations to the future, to non-humans, and complexity. In turn, this focus on understanding the earth as home rather than surface might place less emphasis on the quality of cross-surface relations, where these would contradict the holistic 'eco' ethics.

This paper has focused on geography because our commitment to consideration of earth is placed very centrally in the naming of the discipline. However, this discussion of earth is intended to be read alongside the much broader rethinking of self and humanity that has occurred across social theory and social sciences. While there has been extensive work on the 'post-human' (Braidotti, 2013) the moves towards rethinking the earth part of the humanity-earth relationship. In the same way that a post-humanist understanding of the 'human' seeks to expand and complement these other frameworks, so too have I attempted to posit the 'eco' earth as complementary to the 'geo' earth. Both emphasise our connections to and interactions with others in various ways. Both imply that changes to specific places will shape and alter other places in ways that may be difficult to understand and predict; both contain space for complexity. What an ecosophical geography might offer, then, is an approach which sees a deeper relationality to a more contingent home. Approaches drawing deep ecology value this complexity and life inherently, whereas a Guattarian ecosophy is more comfortable with identifying this relation to the earth as a pragmatic choice for human survival. Whatever conceptual tradition drawn from, however, the key point of this article is that a deeper and more considered exploration of the eco would provide a productive place for geography to contribute to the reconceptualization of the human-earth relationship by paying the same attention to the 'earth-body' as we have to humanity.

Aiken, G. 2012: Community Transitions to Low Carbon Futures in the Transition Towns Network (TTN), Geography Compass, 6: 89-99.

Amin, A. 2004: Regions Unbound: Towards a New Politics of Place, Geografiska Annaler. Series B, Human Geography, 86: 33-44.

Bastian, M. 2012: Fatally Confused: Telling the Time in the Midst of Ecological Crises, Environmental Philosophy, 9: 23-48.

Bateson, G. 1973: Steps to an Ecology of Mind. Paladin. St Albans, Australia. 510 p p. 
Robert Shaw, 2017. Geografiska Annaler B. Final Author's Pre-Print Version

Bennett, J. 2004: The Force of Things: Steps towards an Ecology of Matter, Political Theory, 32: 347372.

Bille, M. 2015: Lighting up cosy atmospheres in Denmark, Emotion, Space and Society, 15: 56-63.

Bogard, P. 2011: Why dark skies? In Bogard, P. (ed.): Let There Be Night. University of Nevada Press. Reno. (1-8 p).

Bonta, M. and Protevi, J. 2004: Deleuze and Geophilosophy : A Guide and Glossary Edinburgh. Edinburgh Unviersity Press.

Bosworth, K. 2016: Thinking permeable matter through feminist geophilosophy: Environmental knowledge controversy and the materiality of hydrogeologic processes, Environment and Planning D: Society and Space, Online Early Acess.

Braidotti, R. 2013: The Posthuman. Polity Press. Cambridge.

Brenner, N. 2013: Theses on Urbanization, Public Culture, 25: 85-114.

Bulkeley, H. 2010: Cities and the Governing of Climate Change, Annual Review of Environment and Resources, 35: 229-253.

Castree, N. 2014: Geography and the Anthropocene II: Current Contributions, Geography Compass, 8: 450-463.

Castro, M., Jara, A. J. and Skarmeta, A. F. G. 2013: Smart Lighting Solutions for Smart Cities. Advanced Information Networking and Applications Workshops (WAINA), 2013 27th International Conference on. (1374-1379 p).

Clark, N. 2016: Anthropocene bodies, geological time and the crisis of natality, Body and Society, Online Early Access.

Costa, M. A. D., Costa, G. H., dos Santos, A. S., Schuch, L. and Pinheiro, J. R. 2009: A high efficiency autonomous street lighting system based on solar energy and LEDs. Power Electronics Conference, 2009. COBEP '09. Brazilian. (265-273 p).

Daniel, J. 2011: In Praise of Darkness. In Bogard, P. (ed.): Let There Be Night. University of Nevada Press. Las Vegas. (21-29 p).

Darling, J. 2009: Thinking Beyond Place: The Responsibilities of a Relational Spatial Politics, Geography Compass, 3: 1938-1954.

Deleuze, G. and Guattari, F. 1987: A Thousand Plateaus : Capitalism and Schizophrenia. University of Minnesota Press. Minneapolis. xix, 610p p.

Deleuze, G. and Guattari, F. 1994: What is Philosophy. Verso. London.

Demant, J. 2009: When alcohol acts: An actor-network approach to teenagers, alcohol and parties, Body \& Society, 15: 25-46.

Derrida, J. 1993: Structure, sign, and play in the discourse of the human sciences, $A$ postmodern reader: 223-242.

Drengson, A. 1995: Shifting Paradigms: From Technocrat to Planetary Person. In Drengson, A. and Inoue, Y. (eds.): The Deep Ecology Movement: An Introductory Anthology. North Atlantic Books. Berkley. (74-100 p).

Edensor, T. 2013: Reconnecting with darkness: gloomy landscapes, lightless places, Social \& Cultural Geography, 14: 446-465.

Edensor, T. 2015: The gloomy city: rethinking the relationship between light and dark, Urban Studies, 52: 422-438.

Farrington, D. P. and Welsh, B. C. 2002: Effects of improved street lighting on crime: a systematic review. Home Office Research Study. Home Office. London.

Forsyth, I., Lorimer, H., Merriman, P. and Robinson, J. 2013: What are Surfaces?, Environment and Planning A, 45: 1013-1020.

Gaston, K. J., Gaston, S., Bennie, J. and Hopkins, J. 2014: Benefits and costs of artificial nighttime lighting of the environment, Environmental Reviews, 23: 14-23.

Genosko, G. 2000: The Life and Work of Felix Guattari: From Transversality to Ecosophy. In Guattari, F. (ed.): The Three Ecologies. Continuum. London. (46-78 p). 
Genosko, G. 2009: Subjectivity and Art in Guattari's Three Ecologies. In Herzogenrath, B. (ed.): Deleuz-Guattari and Ecology. Plagrace. Basingstoke. (102-115 p).

Graham, S. and McFarlane, C. 2014: Introduction: infrastrcutural lives. In Graham, S. and McFarlane, C. (eds.): Infrastrcutural Lives: Urban Infrastructure in Context. Routledge. (1-14 p).

Gregory, D. 1994: Geographical Imaginations. Blackwell. Cambridge, Ma. xii, 442 p p.

Guattari, F. 1995: Chaosmosis:An Ethico-Aesthetic Paradigm. Powet. Sydney.

Guattari, F. 1996: Remaking Social Practices. In Genosko, G. (ed.): The Guattari Reader. Blackwell. Oxford. (262-272 p).

Guattari, F. 2000: The Three Ecologies. Athlone Press. London ; New Brunswick, N.J. 174 p. p.

Harrison, P. 2007a: "How Shall I say it...? Relating the nonrelational, Environment and Planning A, 39: 590-608.

Harrison, P. 2007b: The Space between Us: Opening Remarks on the Concept of Dwelling, Environment and Planning D: Society and Space, 25: 625-647.

Harrison, P. 2011: flētum: a prayer for X, Area, 43: 158-161.

Hartshorne, R. 1939a: The Nature of Geography: A Critical Survey of Current Thought in the Light of the Past, Annals of the Association of American Geographers, 29: 173-412.

Hartshorne, R. 1939b: The Nature of Geography: A Critical Survey of Current Thought in the Light of the Past (Conclusion), Annals of the Association of American Geographers, 29: 413-658.

Herzogenrath, B. 2009: Natuer, Geophilosophy, Machinic, Ecosophy. In Herzogenrath, B. (ed.): Deleuz-Guattari and Ecology. Plagrace. Basingstoke. (1-22 p).

Jacobs, J. 1961: The Death and Life of Great American Cities. Random House. New York.

Jakle, J. A. 2001: City Lights. John Hopkins University Press. Baltimore.

Jazeel, T. and McFarlane, C. 2010: The limits of responsibility: a postcolonial politics of academic knowledge production, Transactions of the Institute of British Geographers, 35: 109-124.

Kinpaisby, M. 2008: Taking stock of participatory geographies: envisioning the communiversity, Transactions of the Institute of British Geographers, 33: 292-299.

Kitchin, R. 2014: The data revolution: Big data, open data, data infrastructures and their consequences. Sage.

Kostic, M. and Djokic, L. 2009: Recommendations for energy efficient and visually acceptable street lighting, Energy, 34: 1565-1572.

Lata, I. B. and Minca, C. 2016: The surface and the abyss/Rethinking topology, Environment and Planning D: Society and Space, 34: 438-455.

Lawhon, M. and Murphy, J. T. 2012: Socio-technical regimes and sustainability transitions: Insights from political ecology, Progress in Human Geography, 36: 354-378.

Lee, C. 2015: Anead and Alight in Johannesburg, 1886-1936. In Isenstadt, S., Maile-Petty, M. and Neumann, D. (eds.): Cities of Light: Two Centuries of Ubran Illumination. Routledege. London. (96-100 p).

Leighly, J. 1938: Methodologic Controversy in Nineteenth Century German Geography, Annals of the Association of American Geographers, 28: 238-258.

Maskit, J. 2009: Subjectivity, Desire and the Problem of Consumption. In Herzogenrath, B. (ed.): Deleuz-Guattari and Ecology. Plagrace. Basingstoke. (129-144 p).

Massey, D. 2004: Geographies of Responsibility, Geografiska Annaler: Series B, Human Geography, 86: 5-18.

McCormack, D. 2009: Aerostatic spacing: on things becoming lighter than air, Transactions of the Institute of British Geographers, 34: 25-41.

Meillassoux, Q. 2008: After Finitude. Continuum. London.

Miller, D. 2001: Behind closed doors. In Miller, D. (ed.): Home Possessions: Material Culture Behind Closed Doors. Berg. Oxford. (1-22 p).

Morton, T. 2010a: The ecological thought. Harvard University Press. Cambridge, Mass. ; London.

Morton, T. 2010b: Thinking Ecology: The Mesh, The Strange Stranger and the Beautiful Soul, Collapse, 6: 195-223. 
Naess, A. 1989: Ecology, Community and Lifestyle. Cambridge Unviersity Press. Cambridge.

Pain, R., Macfarlane, R., Turner, K. and Gill, S. 2006: 'When, where, if, and but': qualifying GIS and the effect of streetlighting on crime and fear, Environment and Planning A, 38: 2055-2074.

Painter, K. 1996: The influence of street lighting improvements on crime, fear and pedestrian street use, after dark, Landscape and Urban Planning, 35: 193-201.

Painter, K. A. and Farrington, D. P. 2001: The financial benefits of improved street lighting, based on crime reduction, Lighting Research and Technology, 33: 3-10.

Peck, J. 2012: Austerity urbanism, City, 16: 626-655.

Popke, J. 2007: Geography and ethics: spaces of cosmopolitan responsibility, Progress in Human Geography, 31: 509.

Rose, G. 1993: Feminism and geography : the limits of geographical knowledge. Polity. Cambridge.

Rose, G. 1995: Distance, Surface, Elsewhere: A Feminist Critique of the Space of Phallocentric Self/Knowledge, Environment and Planning D: Society and Space, 13: 761-781.

Rothenberg, D. 1995: A Platform of Deep Ecology. In Drengson, A. and Inoue, Y. (eds.): The Deep Ecology Movement: An Introductory Anthology. North Atlantic Books. Berkley. (155-168 p).

Schivelbusch, W. 1988: Disenchanted Night. Berg Publishers. Oxford.

Shaw, R. 2014: Streetlighting in England and Wales: new technologies and uncertainty in the assemblage of streetlighting infrastructure, Environment and Planning A, 46: 2228-2242.

Shaw, R. 2015: Bringing Deleuze and Guattari down to Earth through Gregory Bateson: Plateaus, Rhizomes and Ecosophical Subjectivity, Theory, Culture \& Society, 32: 151-171.

Springer, S. 2014: Earth Writing. Academai.edu.

Stauffer, R. C. 1957: Haeckel, Darwin, and Ecology, The Quarterly Review of Biology, 32: 138-144.

Steinbach, R., Perkins, C., Tompson, L., Johnson, S., Armstrong, B., Green, J., Grundy, C., Wilkinson, P. and Edwards, P. 2015: The effect of reduced street lighting on road casualties and crime in England and Wales: controlled interrupted time series analysis, Journal of Epidemiology and Community Health, Online Early Access.

Whatmore, S. 2006: Materialist returns: practising cultural geography in and for a more-than-human world, Cultural Geographies, 13: 600-609.

Whittlesey, D. 1945: The Horizon of Geography, Annals of the Association of American Geographers, 35: 1-36.

Wylie, J. 2006: Depths and Folds: On Landscape and the Gazing Subject, Environment and Planning D: Society and Space, 24: 519-535. 